Annals of Warsaw University of Life Sciences - SGGW

Land Reclamation No 50 (1), 2018: 19-31

(Ann. Warsaw Univ. of Life Sci. - SGGW, Land Reclam. 50 (1), 2018)

\title{
The assessment of ecological connectivity of the Chojnowski Landscape Park - the regional approach
}

\author{
AGATA PAWŁAT-ZAWRZYKRAJ, MACIEJ BRZANK \\ Faculty of Civil and Environmental Engineering, Warsaw University of Life Sciences - SGGW
}

\begin{abstract}
The assessment of ecological connectivity of the Chojnowski Landscape Park - the regional approach. Maintaining ecological connectivity is crucial especially for protected areas located in proximity of a large city. That sort of areas are threatened by urban sprawl which cause natural and semi-natural area loss, landscape fragmentation and isolation. Ecosystem services and biological diversity could be maintained by linking not yet protected areas and treat them as a part of ecological network. The Chojnowski Landscape Park is an example of such protected area which is located in the functional zone of Warsaw. The scope of the study was to delimitate potential ecological corridors linking the Chojnowski Landscape Park with other core areas, assess their functionality and point spots endangered by the ecological connectivity loss. Data from national institutions and the Corine land cover 2012 were used to make GIS analyses. Application of buffering and re-buffering methods allowed to indicate potential expansion zones and helped to delimitate ecological corridors linking the Chojnowski Landscape Park with surrounding landscape parks and national ecological corridors. The strongest and the most numerous connections were indicated towards Mazowiecki Landscape Park. Other potential ecological corridors were assessed as highly endangered, mostly because of infrastructural barriers. Despite the existence of areas of landscape protection as another form of the nature conservation of terrains located between parks, law regulations allow to efficiently protect only the ecological corridors along river valleys. The local spatial planning actions are needed, because that will be the most efficient way of preserving ecological corridors of Chojnowski Landscape Park.
\end{abstract}

Key words: ecological corridors, ecological network, spatial planning, nodal zones, natural protected areas

\section{INTRODUCTION}

Protected areas, such as national landscape parks or nature reserves, located in urban agglomerations are a rich source of ecosystem services, but at the same time are threatened by anthropopression. The proximity of a large city is connected with a spread of development and endangerment of the natural and semi-natural area loss, the landscape fragmentation and the isolation (EEA 2006, 2012). That sort of protected areas should be a part of an ecological network as a regional or national nodal zone to maintain the biological diversity, uniqueness and availability of ecosystem services (Jongman et al. 2004, Bennett and Mulongoy 2006, Worboys and Lockwood 2010). The ecological network is based on a system of large, biologically rich areas (core areas, nodal zones), usually partially or entirely under some kind of the nature conservation, which are representative for natural regions and are connected by ecological corridors, to enhance the biological diversity to a greater extent than in an un- 
connected form (Liro 1998, Bouwma et al. 2002, Bennett and Mulongoy 2006, Jongman 2009). Ecological corridors (greenways) are natural, semi-natural and even anthropogenic, linear or nonlinear, continuous or discontinuous landscape elements enable to maintain ecological connectivity including migration, dispersion and genetic exchange of species (Bennett 2003, Pchałek et al. 2011, Pawłat-Zawrzykraj and Podawca 2016). Mentioned components could be surrounded by buffer zones and sustainableuse areas (Bennett and Mulongoy 2006). Protection of the ecological connectivity is possible mainly by proper legal tools and the effective spatial planning (Civic et al. 2009, Jędrzejewski and Ławreszuk 2009). Both conditions in Poland are not fully met. Legal regulations are not sufficient, for instance the definition of the ecological corridor in the nature protection law is unclear and there is a lack of legal tools or they are not efficient to establish and conserve elements of the ecological network (Pchałek et al. 2011, Brzank and Pawłat-Zawrzykraj 2013). The process of spatial planning is currently partly defective, especially in relation to maintain the ecological connectivity. Currently, the most effective tool for its' protection, is establishing local spatial plans, taking into account ecological corridors together with the most vulnerable spots, before the corridors are built (Jędrzejewski and Ławreszuk 2009, Kistowski and Pchałek 2009, Brzank and Pawłat-Zawrzykraj 2013, Pawłat-Zawrzykraj and Brzank 2013), for instance by allocating they key areas for parks, forests, extensive agricultural lands, with prohibition of housing and fencing or even by repurchasing of land. Finally, location and construc- tion of animal bridges and passages for spots where the ecological connectivity is endangered by infrastructural barriers, especially on expressways and motorways, should be also mentioned.

The Chojnowski Landscape Park (Chojnowski LP) is that sort of protected area located in the functional zone of a large city. Distance of only $6 \mathrm{~km}$ from the boarder of the park to the boarder of Warsaw determines the significant pressure from the urban sprawl. The greatest impact of built-up areas is seen from fast growing Piaseczno city from the North-West, Konstancin-Jeziorna city from the North and many suburban villages located in the boarders of the Chojnowski LP and its buffer zone. The protection plan for the Chojnowski Landscape Park is currently being prepared and only the project from year 2008 is available. The protection plan is a document dedicated to the specific area and provides tasks and regulations binding municipalities in boarders of the Park. The project referred the Chojnowski Landscape Park as part of a concept called greenbelt of Warsaw, included also in the spatial development plan of the voivodship (MBPR 2015) and as an element of the protected areas system which spreads from the Mazowiecki Landscape Park in the East to the Bolimowski Landscape Park in the West (ChPK 2008). In spite of records about the need to maintain ecological corridors in the project of the protection plan for the Park and spatial plans of surrounding municipalities, vanishing of the ecological connectivity is noticed (Pawłat-Zawrzykraj and Brzank 2015). The ecological network should be hierarchical and implemented on every level of planning (Bennett and 
Wit 2001, Kistowski and Pchałek 2009, Pchałek et al. 2011). The concept of spatial development of the country for Poland (The National Spatial Development Concept 2030, 2011) includes the network of ecological corridors prepared for Ministry of the Environment (Jędrzejewski et al. 2011). According to that network, the Chojnowski LP is situated outside of the national ecological corridors but in close proximity to the corridor of central Vistula valley (Fig. 1).
The national policy contains records obligating to expand the ecological links on lower planning levels, but it is not implemented properly yet (Bernatek 2011). Therefore, it is crucial to find and assess potential ecological corridors connecting the Chojnowski LP with other core areas creating regional ecological network, especially for the areas endangered by the fast urban sprawl.

The scope of the study was to delimitate potential ecological corridors

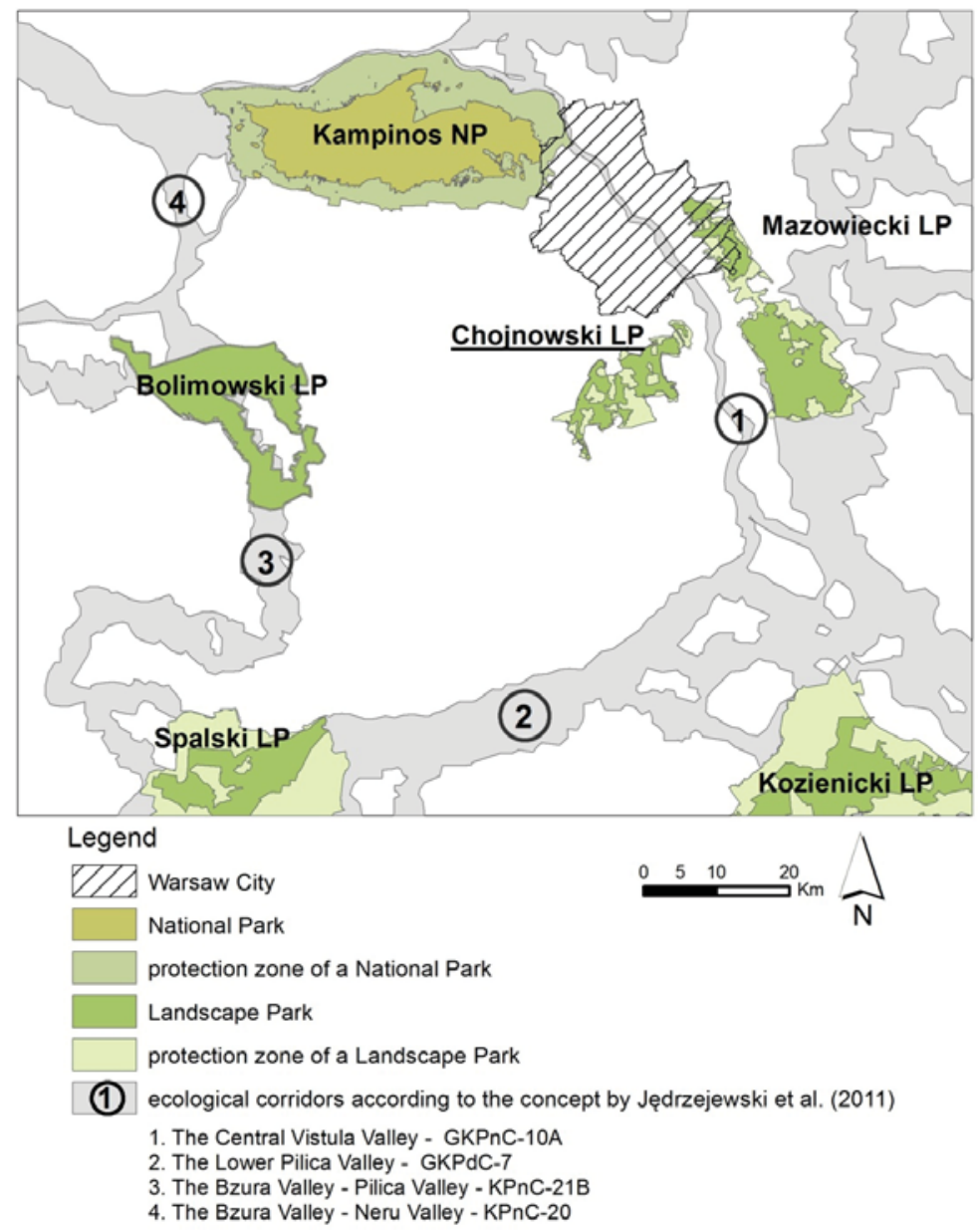

FIGURE 1. Location of the Chojnowski Landscape Park in relation to the neighbouring protected areas and ecological corridors of the national and regional importance 
linking the Chojnowski Landscape Park with other core areas, assessment of their functionality and pointing spots endangered of the ecological connectivity loss. The utilitarian scope was to indicate actions, that can be implemented by spatial policies in municipalities located in the area of delimitated ecological corridors.

\section{METHODS}

The authors have made an a priori assumption that it is significant, in terms of the biodiversity conservation of the Chojnowski LP, to maintain the ecological connectivity between the park and other protected areas located within its vicinity. The role of the regional or subregional nodal zone due to their special natural and landscape values and high level of biodiversity was assigned to the following areas:

- Bolimowski Landscape Park - in the West;

- Spalski Landscape Park - in the South-West;

- Kozienicki Landscape Park - in the South-East;

- Mazowiecki Landscape Park - in the East and on the right bank of the Vistula river (Fig. 1).

The spatial range of the landscape parks and their protection zones was distinguished as a part of a system of protected areas in Poland in Shapefile format (.shp), provided for by General Directorate for Environmental Protection (sdi.gdos.gov.pl).

At this preliminary stage of the study, the location of the park within the national ecological corridors, according the latest concept developed for Poland by Jędrzejewski et al. (2011), was also ana- lyzed. The Chojnowski LP as opposed to other surrounding parks is not included as a part of the network on national level and the nearest ecological corridor is the central Vistula valley (GKPnC-10A) in the East (Fig. 1).

The first step to identify the potential ecological corridors for the Chojnowski LP was to select open landscape areas of natural or semi-natural vegetation types from Corine Land Cover - clc 2012. The data set was retrieved from the website of the Chief Inspectorate of Environmental Protection (clc.gios.gov.pl). The following land cover types were designated: woodlands (corine land cover code - 312), transitional woodland-shrub (clc - 324), grasslands (clc - 231), marshes (clc-231), water courses and bodies (clc - 512). These are areas that provide the natural and permanent or periodical habitat for many flora and fauna species.

The next steps for designation of potential ecological corridors were applied from the procedure that can be called buffering and re-buffering, negative and positive buffering (Hänel 2007, Neubert et al. 2010) or swelling and shrinking (Berthoud 2010). It is carried out in two phases and starts with buffering all selected open landscape areas with an outer buffer. The buffer distance implemented in analysed studies should correspond to the potential of species associated with the continuum to move outside the extension zone without any particular difficulty (Berthoud 2010). Therefore, it is varied and depends of the land-use type and the significance (level) of the ecological connections. In case of majority of mobile species, according to Berthound (2010), most of the expansion zones are normally in the range of 100-500 m. Neubert et al. 
(2010) in the research conducted on the ecological corridors of European importance, applied buffering for all selected land cover classes up to $2,000 \mathrm{~m}$. Hänel (2007) in the methodological guide for ecological network building in Germany proposed several classes of mapping from 100,250 and up to $2,000 \mathrm{~m}$ to indicate ecological corridors at various stages of planning. In that method the distance class of $250 \mathrm{~m}$ was referred as proper to the regional scale and defining a high percentage of biologically rich areas (Hänel 2007, Riecken and Finck 2009). In the presented study the $250 \mathrm{~m}$ distance was applied for buffering and re-buffering procedure to indicate the regional potential ecological connectivity.

The result of "positive" buffering of $250 \mathrm{~m}$ enables to join extension zones that are initially separated and to point out the potential connection between them. The second phase of applied procedure basically consists of buffering of matrix that was obtained in the previous phase by the same value (Fig. 2).

The buffering and re-buffering procedure enabled to set up structures that have direct or indirect spatial connectivity. Due to the additional land-use analysis the most likely routes linking some of the structures were indicated. The principle of the "path of least effort and least risk", which ensures that the shortest trajectory is always the one most frequently taken (Berthoud 2010) have been applied. Potential regional ecological corridors linking surrounding landscape parks were delimitated and every segment was named (Fig. 3).
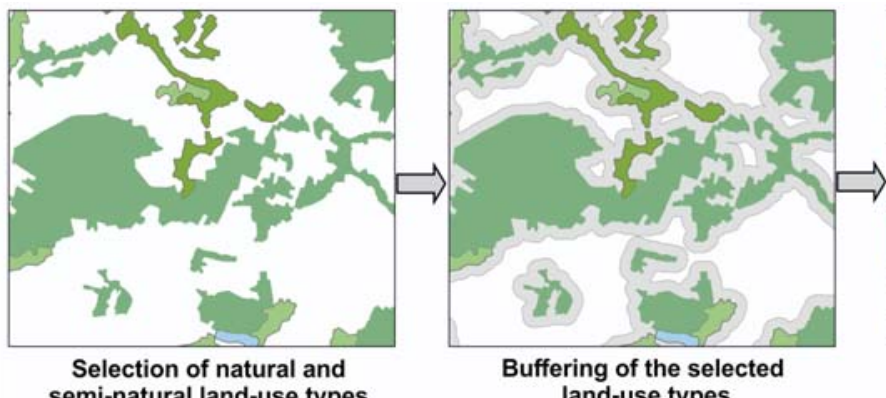

Buffering of the selected land-use types

\section{Legend}

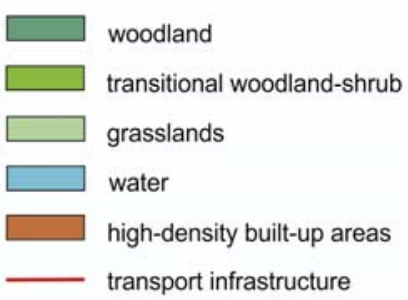

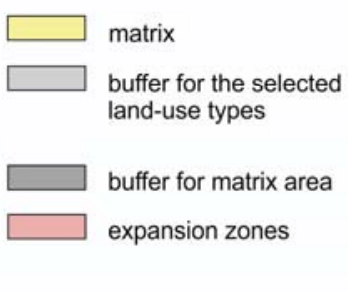

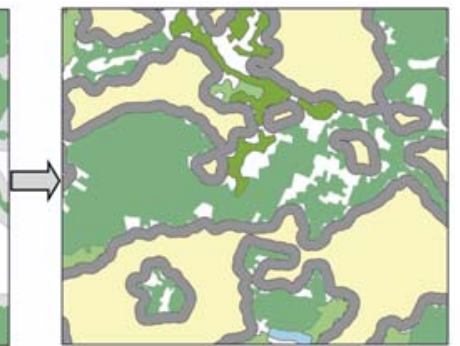

Setting up the buffer for the matrix

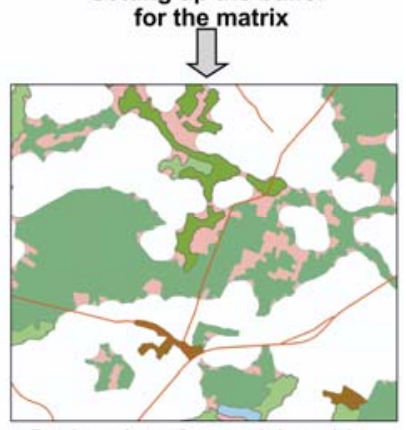

Designation of potential corridors by re-buffering and identyfication of anthropogenic barriers

FIGURE 2. The methodological scheme of the delimitation of potential ecological corridors 

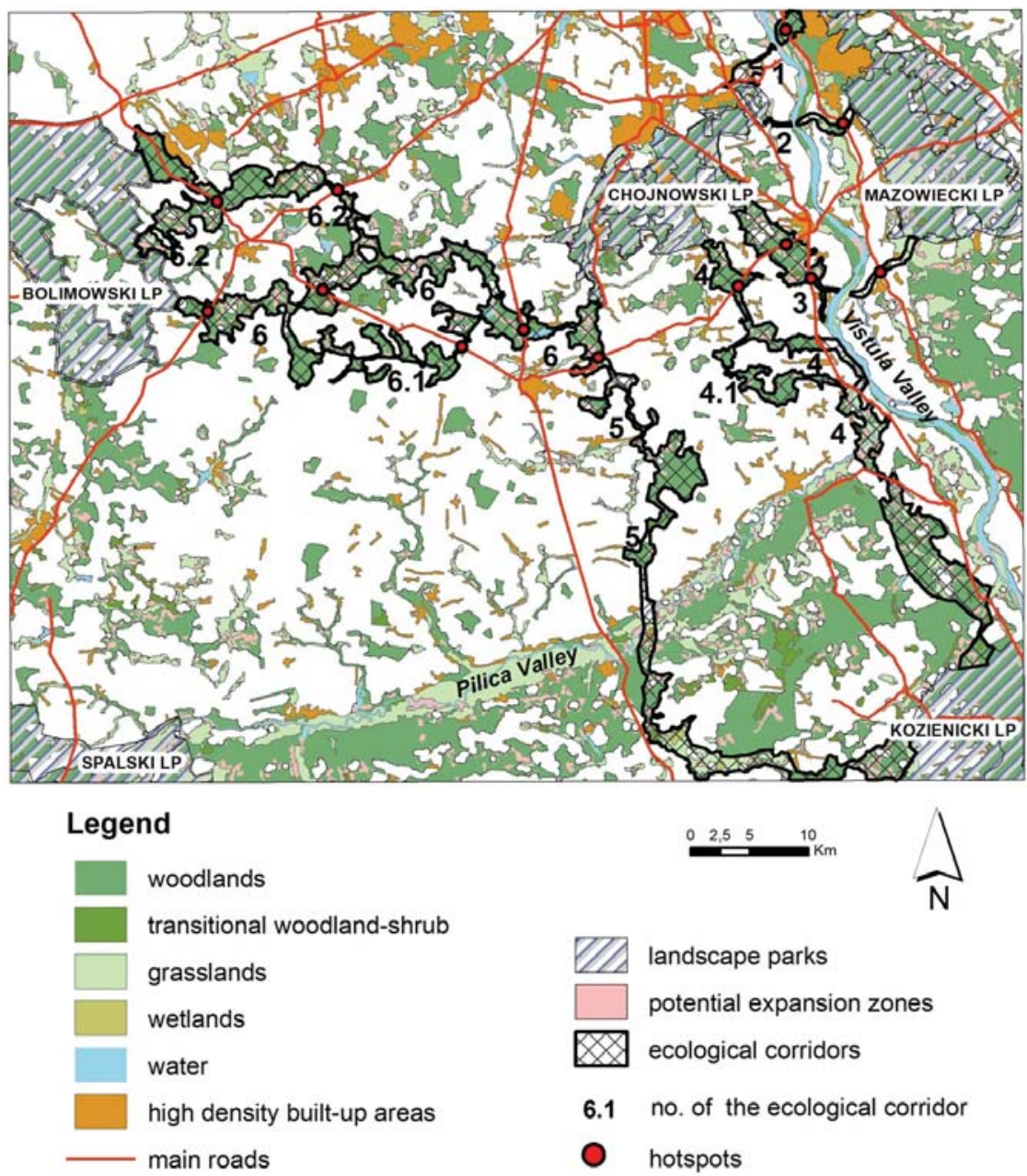

FIGURE 3. The spatial distribution of the selected potential ecological corridors

Functioning of ecological corridors highly depends on existing spatial barriers (hotspots), such as: high-flow transport infrastructure and build-up areas (Seiler 2001, Kurek 2010a, b, EEA 2012) and therefore that aspect was included in the next phase of the study. National and regional categories (A, S, GP) of roads due to the traffic and construction were considered and taken from BDOT10k shared by Geodetic and Cartographic Documentation Centre. The mean daily annual traffic of vehicles in year 2015 from General Directorate for National Roads and Motorways was obtained to include the barrier effect of roads (GDDKiA 2016). High-density built-up areas were created as a layer based on clc 2012 data. Gaps and vulnerable spots in the cohesion of the ecological network were analyzed on the basis of an orthophotomap taken from Geoportal (mapy. geoportal.gov.pl) and in several parts verified in the fieldwork. 
Assessment of identified potential ecological corridors is based on several criteria: length, distance in the straight line between regional core areas, number of significant line barriers (main roads with mean daily annual traffic above 10,000 vehicles), narrow segments below $100 \mathrm{~m}$, number of gaps in corridor cohesion, percentage share of gaps in the total length of a corridor or its segment, length of the regional corridor between the CHLP and a river bed within the nearest national ecological corridor

Spatial analysis and maps were made by means of the ArcMap 10.4.1 application being part of the ArcGIS software.

\section{RESULTS AND DISCUSSION}

As a result, the following potential ecological corridors between the Chojnowski LP and other analysed LP were established:

- three ecological corridors connecting Chojnowski LP and Mazowiecki LP - nos 1-3,

- two corridors routed in the direction of Kozienicki LP - nos 4 and 5

- one corridor connecting Chojnowski LP with Bolimowski LP - no 6 with two additional (alternative) branches nos 6.1 and 6.2 .

The selected corridors are displayed on Figure 3 and main elements of the characteristics are presented in the table. In case of the connections with the Spalski Landscape Park and Kampinos National Park it has been recognized that there are mainly indirect links via the national ecological corridors: the central Vistula valley and the lower Pilica valley.

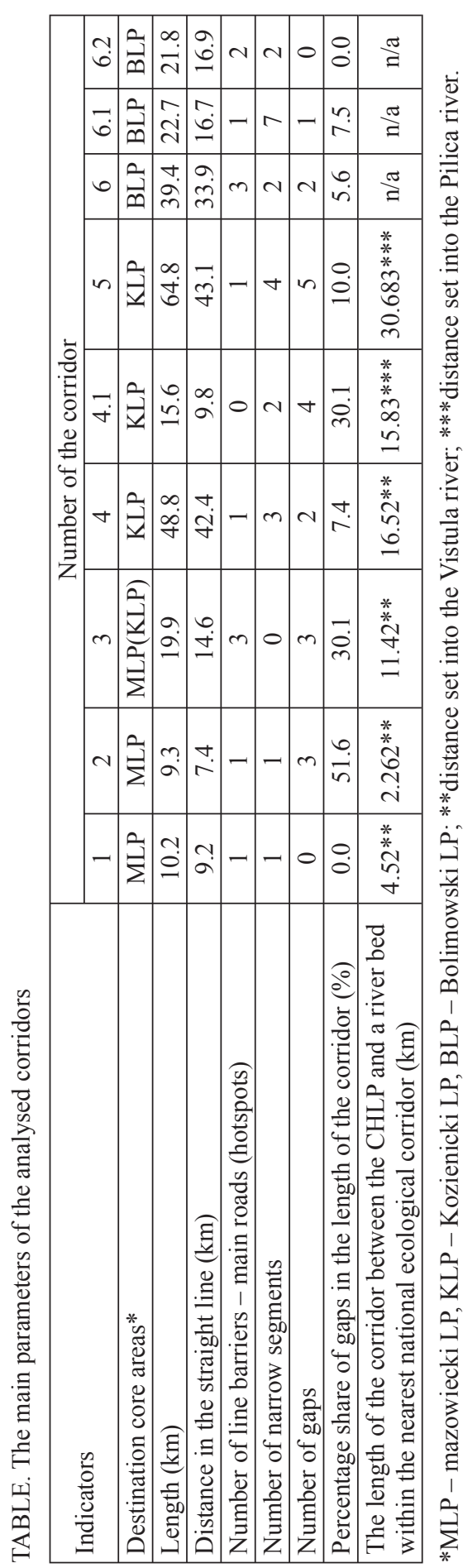


The strongest and the most numerous connections were indicated towards the closest Mazowiecki LP on the East. Mainly due to the shortest distance between the parks, linked by wide and flat Vistula valley. The latter is to serve the role of national ecological corridor. Unfortunately, those areas are strongly functionally and economically associated with Warsaw and thus subject to urban pressure. Municipalities located in that area and bordering with the landscape parks are conscious of the issue. The parks' authorities also try to introduce it into their local policies. Numerous examples demonstrate that the maintaining of the ecological connectivity is inefficient (Pawłat-Zawrzykraj and Brzank 2013, Pawłat-Zawrzykraj and Podawca 2016). However, according to the presented study there are still at least two (nos 1 and 2) or even four (nos 3 and 4) potential ecological corridors that can ensure the link between the Chojnowski LP and the parts of ecological network of the national and regional importance.

The ecological corridors identified to the South of the Chojnowski LP might provide connections with the Kozienicki LP through the central Vistula valley and then the lower Pilica valley, which are also the elements of the national ecological network. The forest corridor no 4 goes partly along the Vistula valley to the Pilica valley. The corridor no 5 consist of land-use types associated with the Jeziorka valley, in the north and central parts, and woodlands and grasslands in the southern part. Most of that area maintains the spatial continuity, except a gap in the cohesion located in the extensive agricultural land matrix near the Pilica river and only one line barrier exists.
The strongest urban pressure on this corridor is observed along the western and southern borders of the park, including its' protection zone. Fortunately, keeping the ecological connectivity along the Jeziorka river is favoured by the natural conservation - the Warsaw Protected Landscape Area (The National Spatial Development Concept 2030, 2011). The river is considered to be an important element of the sub-regional ecological network and thus it is also respected in the local policy. The southern part of the corridor is located in slightly less builtup areas with the high share of rural, horticulture and fruit production areas. The other positive fact is that there are few infrastructural barriers that can endanger spatial continuity of the corridor.

The corridor no 6 is the result of a search for ecological connections between Chojnowski LP and Bolimowski LP. This ecological corridor is the most forked and passes through numerous woodland complexes of various sizes, interrupted by grassland with a small number of ponds. The main corridor no 6 can be locally supported by alternative connections (corridor nos 6.1 and 6.2). It shows high landscape and natural values of that part of the region. Protection of that natural or semi-natural landuse types through maintaining the spatial connectivity might be one of the crucial objectives set up in the regional and local environmental policy. Nevertheless, functioning of these potential ecological corridors, as a part of the system linking the Chojnowski LP with the core area Bolimowski LP, highly depends also on infrastructure thresholds. Especially that they are the most crossed by linear barriers with the heavy traffic and with the 
hardly permeable construction. The lack of facilities reducing the negative impact on animals and the urban sprawl along the main roads threat the existence of ecological connections in that area the most. The main hot spots for the ecological corridor are displayed on the Figure 3.

Almost all initially selected potential core areas, that might be important in terms of sustaining biodiversity of the Chojnowski LP are not directly connected to the park. Only the indirect connectivity through national or regional ecological corridors can be considered. The shortest existing connections were indicated between the park and the central Vistula valley. These are connections of high priority for the park and therefore they need to be urgently included in protection recommendations for the local policy.

There is certain probability that the connections identified in the southern part of the analysed area can operate as the link between the Chojnowski LP and the Pilica valley. However, these are the ecological connections that can be even more significant in terms of the local environmental issues and therefore should be included in the environmental municipal policy.

The concept of ecological corridors connecting Chojnowski LP and Bolimowski has substantial reasons, but it is highly endangered due to the existing infrastructural barriers.

The adopted methodology of buffering and re-buffering can be the useful tool for identifying the ecological corridors, especially in terms of the steppingstones structures. The obtained results of the preliminary spatial GIS analysis need to be verified. The crucial issues that should be discussed in this particular case is the LUD. The level of precision of the land use database should be obviously adequate to the scale of the spatial analysis. The Corine land cover was employed for the presented task in a satisfying way, but in case of local or more detailed studies it can be insufficient.

\section{CONCLUSIONS}

1. Spatial distribution and size of existing natural and semi-natural land-use types located at the area surrounding the Chojnowski Landscape Park can be a basis for designating of ecological connections between the park and other core areas - Mazowiecki, Kozienicki and Bolimowski Landscape Parks.

2. Six potential ecological corridors have been indicated: three of them between Chojnowski LP and Mazowiecki LP through the Vistula valley, two - between Chojnowski LP and Kozienicki LP through the Pilica valley and one towards the Bolimowski LP. The connections with the river valleys enables the Chojnowski LP to be linked with the ecological corridors of national importance set up in the latest concept of the Polish ecological network by Jędrzejewski et al. (2011).

3. The designated corridors do not have spatial continuity and their integrity is jeopardised by several infrastructure thresholds. The most likely corridors to operate are those designated between the Chojnowski LP and Mazowiecki LP through the central Vistula valley corridor. This requires 
consistent action that prevent the spread of built up areas.

4. The existing ecological corridors directly connected to the Chojnowski LP are considered to be rather important elements of the sub-regional ecological network. Therefore, their operation, spatial continuity and overall protection should be an important subject of the local (municipal) spatial policy.

\section{REFERENCES}

BENNETT A.F. 2003: Linkages in the Landscape: The Role of Corridors and Connectivity in Wildlife Conservation. IUCN, Gland - Cambridge.

BENNETT G., MULONGOY K.J. 2006: Review of experience with ecological networks, corridors and buffer zones. CBD Technical Series 23. Montreal.

BENNETT G., WIT P. 2001: The Development and Application of Ecological Networks: A Review of Proposals, Plans and Programmes. AIDEnvironment, Amsterdam.

BERNATEK A. 2011: Ocena wdrażania koncepcji korytarzy ekologicznych do planów zagospodarowania przestrzennego województw [Evaluation of the implementation of concept of ecological corridors in plans of spatial development for Voivodship]. WWF Polska, Kraków.

BERTHOUD G. 2010: Methodological guide of the hierarchical ecological networks. Ten years of experiments in Isère. Isere Conseil General, Yverdon-les-Bains.

BOUWMA I.M., JONGMAN R.H.G., BUTOVSKY R.O. 2002: Indicative map of the Pan-European ecological network for central and eastern Europe - technical background document. (ECNC Technical report series). ECNC, Tilburg - Budapest.

BRZANK M., PAWŁAT-ZAWRZYKRAJ A. 2013: Ochrona łączności ekologicznej i bioróżnorodności poprzez narzędzia planowania przestrzennego - spójność sieci Natura 2000 oraz perspektywy delimitacji sieci ekologicznej w Polsce [Ecological connectivity and biodiversity conservation through spatial planning tools - cohesion of Natura 2000 network and delimitation of the ecological network perspectives in Poland]. In: Gospodarowanie $\mathrm{w}$ dolinach rzecznych na obszarach Natura 2000. Wydawnictwo SGGW, Warszawa: 57-72.

Chojnowski Park Krajobrazowy, ChPK 2008: Projekt rozporządzenia wojewody mazowieckiego $\mathrm{w}$ sprawie ustanowienia planu ochrony dla Chojnowskiego Parku Krajobrazowego [A draft regulation of the Mazowieckie voivodeship on the establishment of a protection plan for Chojnowski Landscape Park].

CIVIC K., JONES-WALTERS L., SNETHLAGE M. 2009: Country Overview: Key findings and recommendations. Interactions between policy concerning spatial planning policy and ecological networks in Europe (SPEN - Spatial Planning and Ecological Networks). ECNC,Tilburg.

European Environmental Agency, EEA 2006: Urban sprawl in Europe. The ignored challenge. EEA, Copenhagen.

European Environmental Agency, EEA 2012: Landscape fragmentation in Europe. EEA, Copenhagen.

Generalna Dyrekcja Dróg Krajowych i Autostrad, GDDKIA 2016: Generalny Pomiar Ruchu w roku 2015 [General Traffic Measurement 2015]. Retrieved form gddkia. gov.pl/pl/2551/GPR-2015.

HÄNEL K. 2007: Methodische Grundlagen zur Bewahrung und Wiederherstellung grossräumig funktionsfähiger ökologischer Beziehungen in der räumlichen Umweltplanung. Universität Kassel, Kassel.

JĘDRZEJEWSKI W., ŁAWRESZUK D. 2009: Ochrona łączności ekologicznej w Polsce [Protection of ecological connectivity in Poland]. Zakład Badania Ssaków PAN, Białowieża. 
JĘDRZEJEWSKI W., NOWAK S., STACHURA K., SKIERCZYŃSKI M., MYSŁAJEK R.W., NIEDZIAŁKOWSKI K., JĘDRZEJEWSKA B., WÓJCIK J.M., ZALEWSKAH., PILOT M., GÓRNYM., KUREK R.T., ŚLUSARCZYK R. 2011: Projekt korytarzy ekologicznych łączących Europejską Sieć Natura 2000 w Polsce [Project of ecological corridors linking European Network Natura 2000 in Poland]. Zakład Badania Ssaków PAN, Białowieża.

JONGMAN R.H.G. 2009: Polityka, planowanie i nauka a sieci ekologiczne - przegląd sytuacji w Europie [Policy, planning and science for ecological networks - an overview for Europe]. Zakład Badania Ssaków PAN, Białowieża

JONGMAN R.H.G., KÜLVIK M., KRISTIANSEN I. 2004: European ecological networks and greenways. Landsc. Urban Plan. 68: 305-319.

KISTOWSKI M., PCHAŁEK M. 2009: Natura 2000 w Planowaniu Przestrzennym. Rola Korytarzy Ekologicznych [Natura 2000 - in the spatial planning - the role of ecological corridors]. Ministerstwo Środowiska, Warszawa.

KUREK R.T. 2010a: Zwierzęta i drogi. Ochrona zwierząt przy drogach szybkiego ruchu w Polsce [Animals and roads. Protection of animals on fast roads in Poland]. Stowarzyszenie Pracownia na rzecz Wszystkich Istot, Bystra.

KUREK R.T. 2010b: Poradnik projektowania przejść dla zwierząt i działań ograniczających śmiertelność fauny przy drogach [A guide to design of passages for animals and actions reducing the mortality of fauna by roads]. Stowarzyszenie Pracownia na rzecz Wszystkich Istot, Bystra.

LIRO A. 1998: Strategia wdrażania krajowej sieci ekologicznej ECONET-POLSKA [Strategy for the implementation of the national ecological network ECONET-POLAND]. IUCN - The World Conservation Union and IUCN Fundation Poland, Warszawa.
Mazowieckie Biuro Planowania Regionalnego, MBPR 2015: Plan zagospodarowania przestrzennego województwa mazowieckiego [Spatial Development Plan For The Mazowieckie Voivodeship Regional Assembly].Warszawa.

NEUBERT M., BIANCHIN S., SYRBE R-U., STOCKER C. 2010: Report Gaps in ecological networks. Leibniz Institute of Ecological and Regional Development, Dresden.

PAWŁAT-ZAWRZYKRAJ A., BRZANK M. 2013: Zachowanie ciagłości polityki przestrzennej gminy w zakresie tworzenia sieci ekologicznej na przykładzie gminy Góra Kalwaria [Continuity of spatial management of a commune in terms of building up its ecological network on the example of the Commune Góra Kalwaria]. Prz. Nauk. Inż. Kształt. Środ. 62: 402-412.

PAWŁAT-ZAWRZYKRAJ A., BRZANK M. 2015: Ocena funkcjonowania korytarzy ekologicznych w kontekście zachodzących zmian $\mathrm{w}$ zagospodarowaniu przestrzennym gminy [Evaluation of the ecological corridors in the context of land changes in the commune]. Infrastruktura i Ekologia Terenów Wiejskich 4 (1): 1021-1033.

PAWŁAT-ZAWRZYKRAJ A., PODAWCA K. 2016: Implementation of ecological network in existing conditions of municipal spatial management. Ann. Warsaw Univ. Life Sci. - SGGW, Land Reclam. 48 (4): 299-312.

PCHAŁEK M., KUPCZYK P., MATYJASIAK P., JUCHNIK A. 2011: Efektywność ochrony korytarzy ekologicznych. Koncepcja zmian legislacyjnych [The effectiveness of the protection of ecological corridors. The concept of legislative changes]. WWF Polska, Warszawa.

RIECKEN U., FINCK P. 2009: Istotne obszary i korytarze niemieckiej sieci ekologicznej o znaczeniu krajowym i międzynarodowym [Core areas and corridors of the German ecological network with 
national and international relevance]. Zakład Badania Ssaków PAN, Białowieża.

Rozporządzenie Nr 3 Wojewody Mazowieckiego z dnia 13 lutego 2007 r. w sprawie Warszawskiego Obszaru Chronionego Krajobrazu [Regulation of the Mazowiecki Voivode of 13 February 2007 concerning the Warsaw Protected Landscape Area]. Dz.U. Woj. Maz. 2007 nr 42, poz. 870.

SEILER A. 2001: Ecological Effects of Roads - A review. Swedish University of Agricultural Sciences, Uppsala.

Uchwała nr 239 Rady Ministrów z dnia 13 grudnia 2011 r. w sprawie przyjęcia Koncepcji Przestrzennego Zagospodarowania Kraju 2030 [The National Spatial Development Concept 2030]. MP 2012, poz. 252.

WORBOYS G., LOCKWOOD M. 2010: Connectivity conservation management: a global guide (with particular reference to mountain connectivity conservation). Erthscan, London.

Streszczenie: Ocena łaczności ekologicznej Chojnowskiego Parku Krajobrazowego - ujęcie regionalne. Zachowanie łączności ekologicznej jest kluczowe szczególnie na obszarach chronionych znajdujących się w sąsiedztwie dużych aglomeracji miejskich. Obszary tego rodzaju są zagrożone niekontrolowanym rozprzestrzenianiem się zabudowy, co powoduje utratę naturalnych i półnaturalnych obszarów, fragmentację krajobrazu oraz izolację. Funkcje przyrodnicze ekosystemów oraz różnorodność biologiczna mogą być zachowane poprzez połączenie obszarów dotychczas chronionych i włączenie ich do sieci ekologicznej. Chojnowski Park Krajobrazowy jest przykładem tego rodzaju obszaru chronionego, który jest zlokalizowany w funkcjonalnej strefie dużego miasta, jakim jest Warszawa. Celem pracy była delimitacja potencjalnych korytarzy ekologicznych łączących Chojnowski Park Krajobrazowy (ChPK) z innymi obszarami węzłowymi, a także ocena ich funkcjonalności oraz wskazanie obszarów zagrożonych utratą łączności ekologicznej. Dane z Corine land cover 2012 oraz inne uzyskane od krajowych instytucji wykorzystano do przeprowadzenia analiz w środowisku GIS. Zastosowano metodę pozytywnego i negatywnego buforowania do wyznaczenia miejsc potencjalnie możliwej mobilności, co pozwoliło na delimitację połączeń ekologicznych ChPK z otaczającymi parkami krajobrazowymi i korytarzami ekologicznymi rangi krajowej. Najwięcej, choć najkrótszych korytarzy ekologicznych udało się wyznaczyć w otoczeniu Mazowieckiego Parku Krajobrazowego (MPK). Ich funkcjonowanie jest jednak zagrożone presją infrastruktury - sieć dróg z dużym natężeniem ruchu oraz rozprzestrzeniająca się zabudowa. Gminy graniczące z ChPN i MPK są świadome wagi problemu, a parki mogą w pewnym stopniu oddziaływać na ich politykę przestrzenną w kontekście ochrony łączności ekologicznej. Korytarze ekologiczne w kierunku Kozienickiego Parku Krajobrazowego łączą się przeważnie z krajowym korytarzem ekologicznym doliny środkowej Wisły, następnie doliną dolnej Pilicy. Inne zidentyfikowane połączenie jest oceniane na gorsze, gdyż ma luki w ciagłości korytarza i jest zlokalizowane w otoczeniu ekstensywnych obszarów rolniczych. Przecięte jest ono tylko jedną znaczącą barierą liniową. Korytarz ekologiczny w kierunki Bolimowskiego Parku Krajobrazowego wielokrotnie rozwidla się i przebiega przez duże kompleksy leśne. Jest on najliczniej przecięty przez bariery infrastrukturalne (drogi z dużym ruchem kołowym i trudną do pokonania dla fauny konstrukcja). Brak drogowych przejść i przepustów dla zwierząt, niekontrolowane rozprzestrzenianie się zabudowy wzdłuż głównych dróg zagrażają istnieniu łączności ekologicznej w tym rejonie. Autorzy nie odnotowali potencjalnych korytarzy ekologicznych w kierunku Kampinoskiego Parku Narodowego i Spalskiego Parku Krajobrazowego. Mimo że między tymi parkami rozciaga się Warszawski Obszar Chronionego Krajobrazu, aktualne regulacje prawne pozwalają jedynie na skuteczną ochronę korytarzy ekologicznych w dolinach rzecznych. Miejscowe plany zagospodarowania przestrzennego są bezwzględnie potrzebne, ponieważ jedynie one mogą skutecznie zachować korytarze ekologiczne Chojnowskiego Parku Krajobrazowego.

Slowa kluczowe: korytarze ekologiczne, sieć ekologiczna, planowanie przestrzenne, obszary węzłowe, obszary chronionego krajobrazu 
MS received 04.12.2017

MS accepted 15.02.2018

Authors' address:

Agata Pawłat-Zawrzykraj

Wydział Budownictwa i Inżynierii Środowiska

Szkoła Główna Gospodarstwa Wiejskiego

w Warszawie

ul. Nowoursynowska 159, 02-776 Warszawa

Poland

e-mail: agata_pawłat_zawrzykraj@sggw.pl 